\title{
The Performance Appraisal Interview - An Arena for the Reinforcement of Norms for Employeeship
}

I Erica Sandlund

Department of Languages, Karlstad University, Sweden

I Christina Olin-Scheller

Department of Educational Work, Karlstad University, Sweden

I Lina Nyroos

Department of Scandinavian Languages, Uppsala University, Sweden

I Liselotte Jakobsen

Center for Gender Studies, Karlstad University, Sweden

I Cecilia Nahnfeldt

Center for Gender Studies, Karlstad University, Sweden

\begin{abstract}
In the present paper, we report findings from a study of performance appraisal interviews between middle managers and employees. The study is based on analysis of video uptake of authentic performance appraisal interviews, and through detailed examination of participant conduct and orientation, we point to structural mechanisms and institutional norms which limit the possibilities for employees to raise topics connected to negative experiences of stress in performance appraisal talk. It is argued that norms concerning ideal employeeship are shaped by a partly hidden curriculum in the organization which in turn is talked into being in the performance appraisal interviews. The study concludes that empirical attention to the social interplay in performance appraisal interactions reveal how participant conduct aligns or disaligns with institutional and social underpinnings of workplace ideals.
\end{abstract}

\section{KEYWORDS}

Performance appraisal interview / ideal worker / staff development / conversation analysis / hidden curriculum.

$\mathrm{n}$ the present paper, we examine performance appraisal interviews and their potential as arenas for addressing workplace stress. Performance appraisal interviews, also referred to as employee reviews, job appraisal interviews, employee appraisal, employee performance appraisal (Asmuß, 2008), and sometimes also staff development talks (Lindgren, 2001), are often acknowledged as central to human resource management and organizational learning (Mikkelsen, 1998; Asmuß, 2006), and perhaps in Scandinavia in particular, to working life democratization (Lindgren, 2001). One aim of these manager/

Erica Sandlund, Department of Languages, Karlstad University, SE-65188 Karlstad, Sweden.

E-mail: Erica.sandlund@kau.se 
employee dialogues is to deal with employee performance and development in the organization, which also often includes the identification of possible obstacles for reaching individual and organizational goals (Asmu $\beta, 2008)$. As such, appraisal interviews could possibly constitute an arena for broaching and finding solutions to matters like work overload and work-life balance problems. However, as our study demonstrates, questions regarding stress (work-related or otherwise) clash with other institutional agendas in the performance appraisal interview, such as displaying a desired high tolerance for stress, which in turn makes it problematic for employees to raise matters related to their experiences. This, in turn, may result in problems being left unresolved, which in the long run could impact both organizational gain and employee well-being and workforce sustainability.

We argue that in order to understand the reinforcement of organizational practice, it is essential to look at the everyday conduct of members of organizations. Like Acker (1990), we argue that performance appraisal systems constitute important sites for the reinforcement of organizational norms:

\footnotetext{
"The rules of job evaluation, which help to determine pay differences between jobs, are not simply a compilation of managers' values or sets of beliefs, but are the underlying logic or organization that provides at least part of the blueprint for its structure. Every time that job evaluation is used, that structure is created or reinforced" (Acker, 1990, p. 148).
}

In essence, our focus on the social organization of talk about stress stems from an assumption that the performance appraisal interviews is one internal arena of communication where managers display, and employees align or disalign with, underlying assumptions about ideals for employeeship.

\section{Research on performance appraisal interviews as institutional interaction}

For the past few decades, the performance appraisal interview has been deemed to be of central importance for a number of factors related to organizational management and success, such as organizational learning (Scherp, Scherp, Johansson \& Jönsson, 2004), working life democratization (Lindgren 2001), employee satisfaction (Asmuß, 2008), economic growth in relation to measuring employee performance, and the management of employees as human resources (Mikkelsen, 1998; Asmuß, 2008). Scandinavian terms, such as the Swedish medarbetarsamtal and utvecklingssamtal (Mikkelsen, 1998; Lindgren, 2001) translate directly as 'co-worker conversations', 'staff development conversations' or 'development talks'. The terms themselves have a radically different tone than their English language counterpart, something which at least partly can be attributed to Swedish working life legislation and trade union movements that have strongly influenced everyday workplace politics.

Regardless of cultural differences, however, such planned meetings between an employee and a manager appear to share a few core features, such as topics that have been predetermined, the follow-up of employee roles and tasks, and, of course, a belief that recurrent management/employee dialogues lead to positive outcomes both for employees and organizations. The way in which such meetings are implemented in practice (in terms of their frequency, degree of formality, and relative presence of actual appraisal of performance) varies greatly between organizations of different size, type, and national affiliation. 
Attempts at finding descriptive definitions is, consequently, a challenge but Asmuß $(2008$, p. 409) defines performance appraisal interviews as "recurrent strategic interviews between a superior in an organization and an employee that focus on employee performance and development". Gordon and Stewart (2009) describe this interaction type simply as instances of "conversing about performance", which falls under the general scope of performance appraisal (PA) in organizations. The earliest formal PA system recorded dates back to 1887 (Mikkelsen 1998, p. 21), and the performance appraisal interview is one method for performance appraisal where organizational goals are to be realized in individual work plans and objectives for development, something which is also characteristic of the management philosophy Management by Objectives (Drucker 1955). The emphasis on evaluating job performance in relation to organizational objectives is more evident in the latter, while the Scandinavian terminology indicates more of a balance between development and performance.

Mikkelsen (1998) lists a number of common objectives for performance appraisal interviews. These include, among others, setting objectives, assessing organizational competence needs and individual career development ambitions, optimizing organizational and individual performance, motivating employees, and improving collegial relations and overall work environment. There is a widespread belief that performance appraisal interviews (PAIs) is a central tool for evaluating employee performance, and combined with a growing focus on internal communication in organizations (Asmuß, 2008), scholarly interest in PAIs has also grown steadily. However, as Asmuß points out in her review of previous research PAIs, the studies "contribute significantly to our understanding of the conditions surrounding performance appraisal interviews, but they do not reveal anything about what actually happens when the supervisor and the employee meet in a performance appraisal interview" $(2008$, p. 410). On the contrary, empirical studies of PAIs focus almost exclusively on various 'before' and 'after' measurements, such as the relationship between the implementation of performance appraisal and increased organizational success, or the correlation between performance appraisal interviews and job satisfaction (Cf. Roberts, 2002). There is also a plethora of handbooks on planning and conducting performance appraisal interviews (e.g. Fellinger, 2005; Grote, 2002; Jäghult, 1988, Jönsson, 2004). These are often based on interviews with managers or analyses of interview guides or evaluation sheets (Asmu $\beta$, 2008) and an underpinning is generally that managers/supervisors alone can make the interview a success given the right training and preparation. In essence, the interview is portrayed as a communication event driven and controlled by one party as opposed to as a collaborative achievement of both parties (Asmuß, 2008, p. 410). A similar type of interaction is parent-teacher conferences in schools, in Swedish called utvecklingssamtal (transl. 'development conversations'), which is also one of the two most common terms used to denote performance appraisal interviews in Sweden (see, for example, Markström, 2009; Redegard, 2006 \& Hofvendahl, 2006).

Research on performance appraisal interviews as communication events in organizations is limited in Scandinavia; however, a few studies merit particular attention in relation to our study. Engquist (1990) examined six 'staff development' conversations between doctors and their co-workers with a particular focus on components of PAIs that appeared to contribute to an experience of satisfaction among participants. Engquist emphasized the need for metacommunication, particularly with regard to defining the scope and objective of the interaction, and the relationship between participants. This 
relationship is usually hierarchically organized, and Lindgren (2001) demonstrates that the democratic PAI free of power asymmetries is an ideological assumption rather than a practical reality. In her detailed analysis of four 'staff development' conversations, she observed that managers dominated the interactions both quantitatively and in terms of topic management. Interestingly, participants nevertheless reported that they perceived the PAIs as a meeting on equal terms, and Lindgren also noted that the interactions usually finish with agreement/consensus, regardless of the manager dominance throughout the interactions. Her study shows that our experience of roles and asymmetries in institutional interactions may differ from actual practice, something which also underscores the importance of microanalysis of social practice as a complement to reliance on self-report data.

As mentioned above, aspects of performance evaluation are often an inevitable part of the interaction. Balancing possibly competing agendas such as assessment of performance and personal support is not uncomplicated. Managers in PAIs, in Kristensen's (2003) critical analysis, become both examiners and confessors, and employees are characterized as career and development-oriented subjects, which in turn can become one of several tools for disciplining employees. The connection between PAIs and wage negotiation can be perceived as a problem by employees when it comes to discussing personal matters or subjective experience of stress, something which has been noted in passing in a few studies on staff development talk (cf. Hermansson, 2004; Engström, 2005). Another problem, which Asmuß (2008) details in her close examination of PAIs, is actually 'doing performance appraisal', since managers in her material displayed obvious trouble in formulating negative assessments. In her work, social concerns (such as the preference for agreement and the social problematicity associated with delivering criticism) overrode institutional objectives even though performance appraisal was part of the format of the PAI. The more managers attempted to mitigate negative feedback, the longer the appraisal interviews tended to become, and employees were given few opportunities to respond to the suggestions for improvement and to participate actively in problem-solving sequences. Other institutional activity formats that face similar social dilemmas as performance appraisal interviews are, for example, job interviews (e.g. Adelswärd, 1988) and parent-teacherpupil conferences in schools (Hofvendahl, 2006). If the PAI can be viewed as a sort of panopticon (Kristensen, 2003) where employee strengths and weaknesses can be placed under managerial microscope, candidate interviews for jobs can be said to partially share the feature of 'self-marketing', where candidates are focused on portraying themselves in a favorable light. One successful strategy that Adelswärd (1988) identified was how candidates displayed their openness and flexibility by showing that they were able to see their previous experience from different perspectives. Hofvendahl (2006), in his analysis of development talks between teachers, parents, and pupils, noted how certain topics were marked as potentially risky, and teachers often mitigated such topics with reassurances of the normality of certain questions (e.g. "this is something I ask all pupils"). The delivery of problematic questions or assessments in Hofvendahl's data shares many characteristics with the sequences containing negative assessments in Asmuß' (2008) data.

By way of summary, there is a growing interest in the effects of performance appraisal interviews for organizational gain as well as employee well-being. However, relatively little is known about the interactional organization of PAIs. Our study contributes to understanding performance appraisal interviews as social events where values and preferences are constructed, negotiated, and maintained. It also emphasizes the necessity of microanalysis of conduct, as self-reported experience or interview guides reveal only 
part of the complex matrix of institutional and social agendas that merge or clash in the performance appraisal encounter.

\section{Norms and ideals in the workplace}

Expectations on what 'a manager' or 'an employee' is in a particular organization are constructed both inside and outside the workplace, and in both formal and informal interactions (cf. Drew \& Heritage, 1992; Antaki \& Widdicombe, 1998). Norms are often implicit and not verbally expressed or documented. In the 1960s, Jackson (1968) introduced the concept of the hidden curriculum based on empirical work in American classrooms. He formulated a number of unwritten demands on pupils in schools, and demonstrated that in order to be successful, knowledge of particular subjects and topics was not enough. In addition, pupils had to be aware of and master a number of unwritten rules of a classroom, such as the art of waiting, being constantly interrupted when working, participating in activities that are of minimal individual interest, and succumbing to the power structures of the school world. The idea of hidden curricula is still a highly relevant concept and it is often linked to organizational learning (Horn, 2003).

In all institutions, organizational cultures linked to both formal and informal (hidden) curricula are continuously being constructed. As such, the performance appraisal interview is part of a formal curriculum where managers are bound to conduct recurrent meetings with their employees with particular purposes and structure. The interview itself, and the learning that occurs there, is related to specific work tasks as well as to notions of how employees and managers are expected to be and act. In a wider perspective, the hidden curriculum consists of values and expectations on qualifications, knowledge, and employee characteristics that are unspoken, and sometimes even unintended. Studies have shown that such hidden locations are ample breeding ground for the exercising of power (Foucault, 1997; Thornberg, 2004; Granath, 2008; Holte, 2009), and consequently, hidden norms can function as tools for educating and modeling students or employees. Hidden curricula for members of a particular organization can also be discussed in terms of norms for the 'ideal worker' (Acker, 1990; 1992; 2006; Tienari, Quack \& Theobald, 2002). In this line of research, the more general image of the 'ideal' employee includes qualifications, full-time and continuous availability, and workorientation (as opposed to orientations to private spheres of life (Tienari et al. 2002, p. 252). Such descriptions are also gendered, i.e. usually (but not always) corresponds to a man's body and assumptions about masculinity, and in its essential form, requires a clear separation of public and private spheres of life. Such qualities are also characteristic of an approach to work that has been referred to as the ideology of a career life-mode (cf. Jakobsen, 1999).

In the present paper, we focus on institutional and interactional approaches to stress in PAIs, which in turn has observable consequences on ways in which performance appraisal interviews can function as tools in the management of individual and structural problems. The study as a whole is based on three sets of empirical data: a survey, in-depth interviews, and video-recordings of authentic performance appraisal interviews (see Jakobsen et al. 2010) and is part of a larger project on gender and sustainable development in working life. However, in this paper, we focus on the PAI as a communication event in situ and the norms regarding ideal employeeship talked into being by managers and employees. 


\section{Data and method}

Data was collected in a medium-sized organization in the financial sector in southwestern Sweden, and the data presented in this paper is drawn from a corpus of eight performance appraisal interviews were recorded on digital video. Participants came from two different offices in the organization, one fairly small office, and one medium-sized. Five PAIs were recorded at the medium-sized office, and three at the small office, and two managers (both male) and six employees (four men, two women) volunteered to have their PAIs recorded. Participants gave their written informed consent, and were informed that they had the right to withdraw from the study at any point. The researchers only handled the recording equipment at the start and finish of each recording, but left the room as soon as the recording began. The recorded material was transcribed according to conversation analytic conventions (see Atkinson \& Heritage, 1984, and appendix 1) where all details of the interaction, such as laughter, pauses, inbreaths, and overlaps are considered potentially relevant.

Conversation Analysis (CA) (Sacks, Schegloff \& Jefferson, 1974; Sandlund, 2004) was also the analytic approach adopted for the recorded interactions. CA is rooted in American sociology and is an established approach to talk and interaction in a number of disciplines, and to a variety of institutional and everyday contexts. Through detailed examination of recordings and transcriptions of naturally occurring interactions, conversation analysts describe social phenomena and their structural regularities as they are collaboratively constructed in situ by participants themselves. Influences from ethnomethodology (Garfinkel, 1967) are evident in the focus on description and understanding of members' own procedures for achieving intersubjective understanding. The emphasis on the sequential organization of conversations (or, more appropriately, talk-in-interaction), which is a cornerstone of CA, refers to the study of social actions in sequences and turns of interaction, and the analytic focus lies in understanding the internal logic behind each turn and its demonstrable connection to prior and subsequent turns. In line with Asmuß (2008), we strive to uncover the social and institutional underpinnings of how performance appraisal talk is constructed in order to achieve insight into how managers and employees relate to topics and question formats in the interview as such.

With CA, 'norms' are studied on the basis of members' own conduct and observable orientation to social and institutional factors, rather than as a priori theoretical assumptions.

This means that it is in participants' actions and how these actions display a particular understanding of the local context (and also shape next actions) that the institution is "talked into being" (Heritage, 1984, p. 290). Participants in interaction have been observed to be sensitive to underlying structural preferences when they design their turns at talk, and this preference organization of conversations (e.g. Pomerantz, 1984) directs which actions are preferred or dispreferred. Preference, in conversation analytic terms, is not linked to personal or psychologically rooted choices, but rather to different options available at a given point for continuing the conversation. These options are, in turn, built into the design of the prior turn or linked to the overall structural organization of a particular interaction. A classic example is that when a question is launched in conversation, it constructs a local context where there is a structural preference for an answer to come next, and if the response is missing or inadequately fitted to the question, it will be marked as socially problematic, or the addressed recipient is held account- 
able for providing a dispreferred response. In our analyses, the concept of preference is applied to make visible underlying social/institutional norms that participants made relevant, in particular with regard to 'stress' and to how 'the ideal employee' emerges in talk. By uncovering the social interplay in the performance appraisal interview, we illuminate the possibilities and restrictions available to participants for ventilating experienced stress within the PAI. In the transcripts, the English translations of each turn are provided first in boldface italics, and with the Swedish original below. The turn units are translated as literally as possible in order to remain close to the original wording (for transcription conventions applied, see appendix).

\section{Findings}

\section{Interactional management of stress of performance appraisal interviews}

A central finding is that experiences of negative stress are given limited space, and that the interactions instead tended to frame stress as positive and as optimizing performance. This framing, in turn, has consequences for employee possibilities of raising problems of stress and work-life balance. In order to illustrate this recurrent and systematic pattern, we present three selected fragments from the recorded PAIs where the organization's preferred approach to stress is made relevant through participant conduct and orientations.

Fragment (1) below begins with a question from the interview guide that both managers and employees have access to in preparation for the interview. The topic was formulated as "stress level then how do you feel there do you feel that you're stressed often or" (lines 1-2):

Fragment (1) "do you feel that you're stressed often or" (ManA = Manager A, K = male employee)

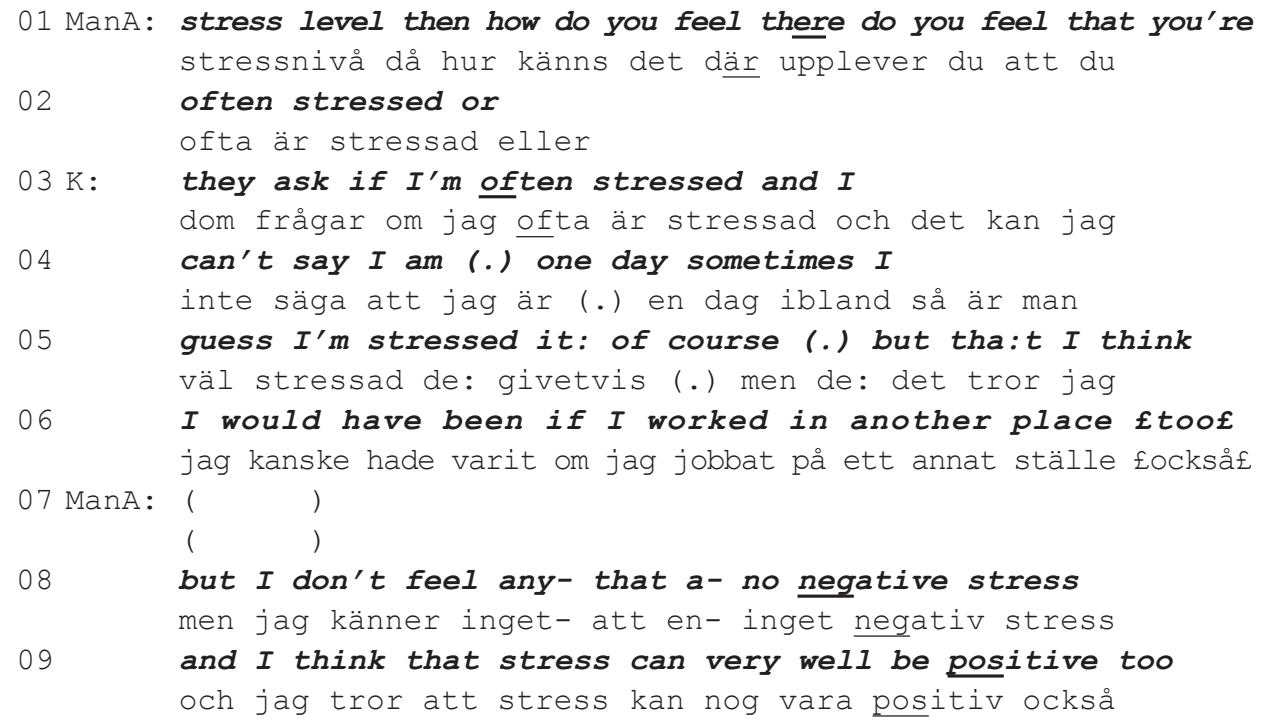




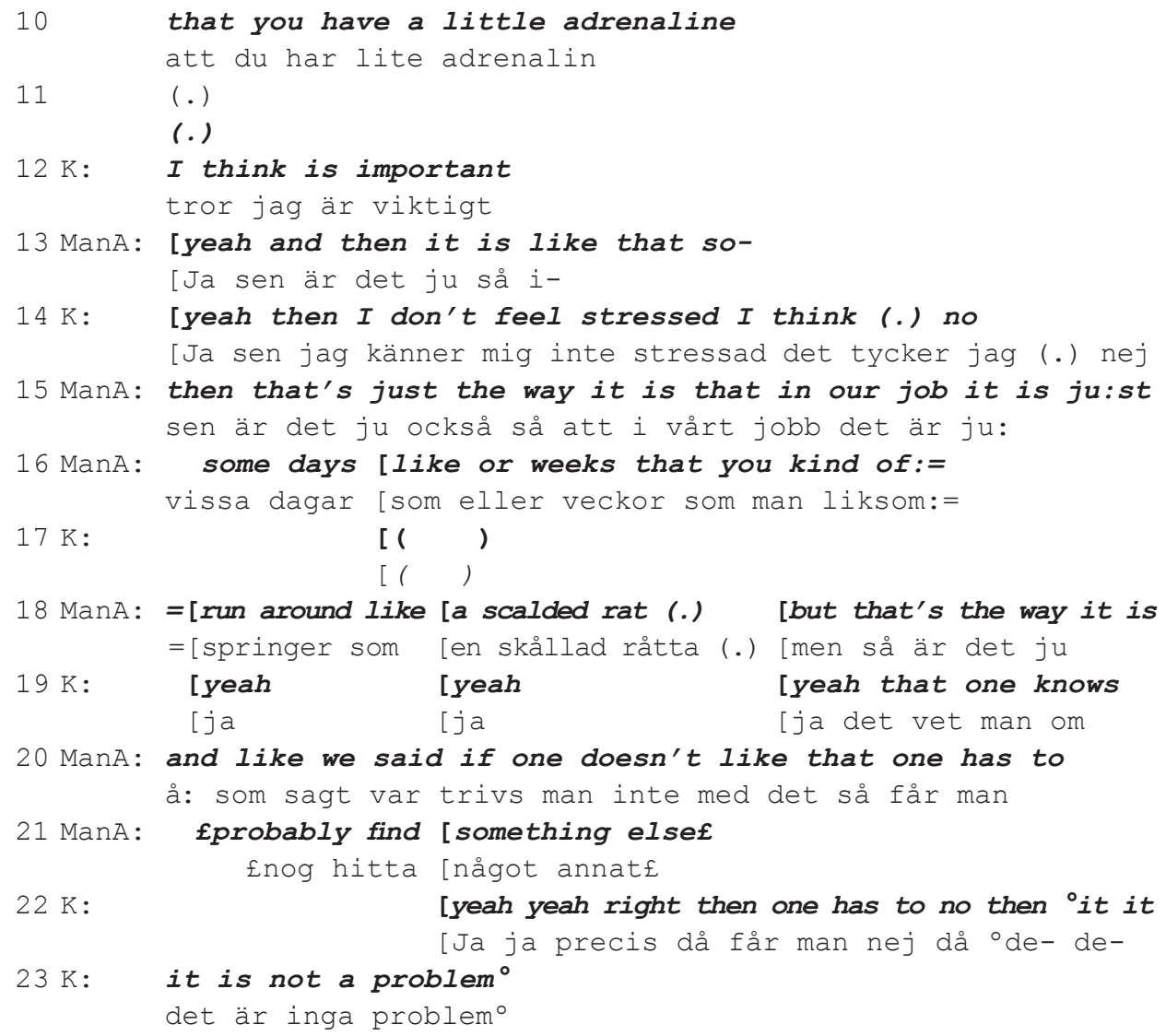

The formulation in lines 01-02, adapted from the pre-set interview guide, is formulated as an invitation to the employee to express possible experiences of stress. In his subsequent turn, the employee $\mathrm{K}$ orients specifically to the word "often" included in the manager's turn, which has an effect on his subsequent response. $\mathrm{K}$ reports that he cannot respond affirmatively to the question, i.e. that he is feeling stressed often, but instead frames stress as a temporary and isolated experience that can, but must not, characterize particular days at work. His response is elaborated in lines 04-07, in which he admits to "of course" feeling stressed on certain days, but that this would have been the case in any job he would have. With this addition, K appears to assume individual responsibility for the experience of stress, rather than attributing it to workplace specificities. Consequently, in this segment, the employee creates a setting where he as an individual, rather than the organization, is responsible for the experience of work-related stress.

In lines $08-10, \mathrm{~K}$ proceeds with a distinction between "negative" and "positive" stress, and characterizes his own experience as positive, which in turn gives rise to "some adrenaline". The manager confirms K's displayed approach to stress with an agreeing "that's just the way it is" in their particular line of work, and elaborates with examples of how he/they/we (Swedish gender- neutral and pronoun "man") sometimes run around like "scalded rats". In this sequence, the manager and the employee together shape the 
experience of stress as a positive presence in their work. In the next turn, the manager further upgrades this position with a rather extreme formulation (lines 20-21): and like we said if one doesn't like that one has to £probably find [something else $£$ ". This type of formulation is packaged as a 'fact', and leaves very little room for $\mathrm{K}$ to disagree without performing a structurally dispreferred action (cf. Pomerantz, 1984). Stress is depicted as a natural and necessary condition for employees in this particular workplace, and as something which employees must be able to 'take' if they want to continue working there. However, we wish to emphasize that the manager's formulation should not be interpreted as a personal viewpoint but rather as a product of the preceding interaction where the employee presented a positive effect of stressful workdays and also responded in the negative to the question of whether he himself felt stressed. In any case, participants jointly construct a preferred approach to stress in this particular organization, that is, as something positive which indirectly results in improved performance.

In the next fragment, the manager $B$ introduces the topic of stress to employee $M$ as "the stress part", which can be heard as something that is possible to delimit clearly:

Fragment (2). "this feeling in your stomach"

(ManB: manager B, $\mathrm{M}=$ male employee)

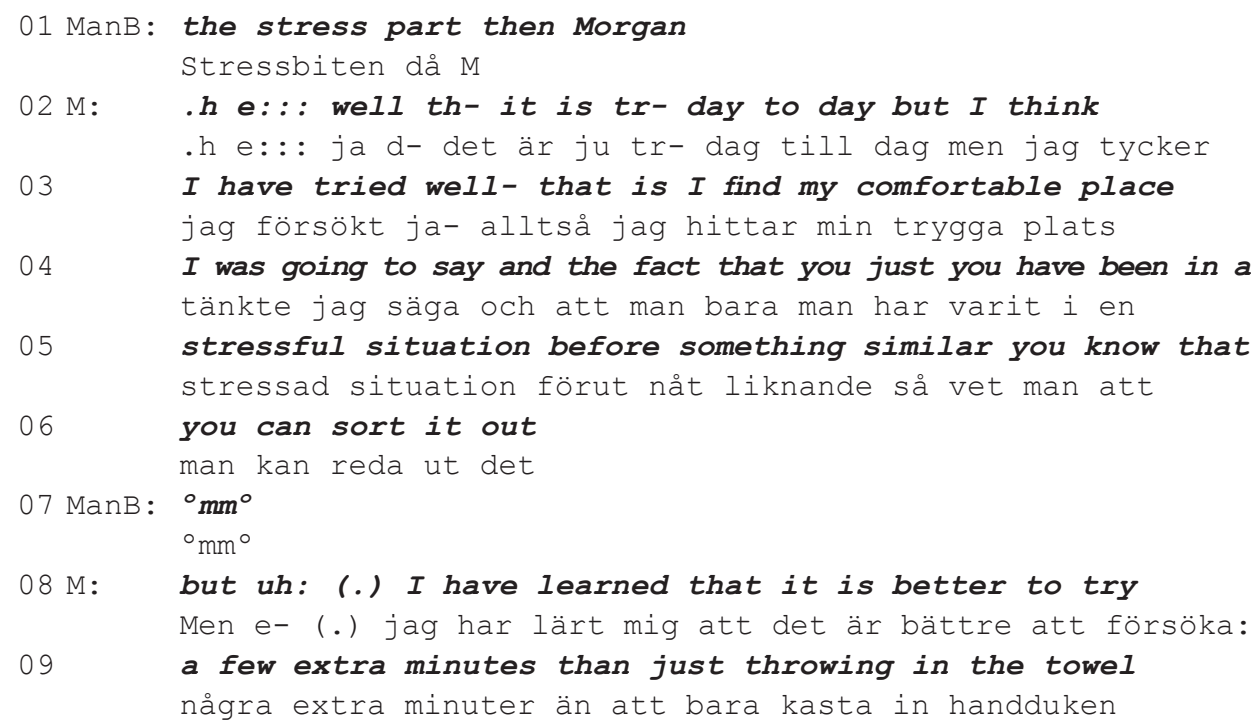

$08 \mathrm{M}$ : but uh: (.) I have learned that it is better to try Men e- (.) jag har lärt mig att det är bättre att försöka:

09 a few extra minutes than just throwing in the towel några extra minuter än att bara kasta in handduken

10 ManB: yeah and I also think we're different people some of us ja och så tror jag vi är olika personer en en del av oss

11 think that stress is just because you get this feeling tror att stress är bara för att det känns lite

12 in your stomach right [it is pretty natural that i magen va [det är ganska naturligt att

13 you get this feeling in your stomach every now and then det känns i magen ibland 
As a response to the question-like turn "the stress part then Morgan", M opts for a rather abstract response describing one way of managing stress that he himself makes use of. Rather than other possible options available to him, such as denying feeling stressed, M's response signals an interpretation of the question as referring to something problematic, and he also displays some trouble formulating an answer in the repeated cutoffs and restarts visible in the initial part of his turn. The remainder of the turn, however, is produced in a more straightforward manner as he appears to find an appropriate answer. He claims to have "found his comfortable place" and offers an account of how stress can be kept at bay: trying a little more and not giving up. With this displayed interpretation and response, $M$ portrays himself as a person who has learned to handle stressful situations, and also constructs stress as a circumstance that is possible to isolate, and which can be manouvered using certain methods. In essence, stress management is depicted as an active choice.

As the account has been completed, the manager does not object to M's initial reaction to the question, but instead confirms it (line 07). The manager's first response is, however, a minimal acknowledgement that can be heard as just a receipt of this information, and after $\mathrm{M}$ has elaborated on his account (lines 08-09) the manager produces a stronger acknowledgement of M's displayed approach to stress by presenting an additional perspective: physical symptoms of stress can very well be something else. With this, the manager shows that physical experiences like "just because you get this feeling in your stomach" are insufficient as evidence of real stress, and thereby also formulates a preferred approach to stress as something that takes a little more than just stomach sensations in order to 'count'. By using "some of us", a sense of shared experience is created, and since the turn is packaged as an assessment (cf. Pomerantz, 1984), there is a structural preference for agreement, which leaves $\mathrm{M}$ with no other preferred alternatives than to agree (line 14). In essence, agreeing with the manager's displayed approach to stress is the only option available to $\mathrm{M}$ in order to keep the interaction socially unproblematic.

In fragment (3), the employee $\mathrm{E}$ and the manager $\mathrm{B}$ propose alternative causes of the employee's experienced stress level, namely, factors outside of the workplace. Another characteristic of this particular sequence is the recurrent pattern of downgrading experienced stress, a strategy frequently deployed by employees in sequences where experienced stress had been made relevant in their own talk.

Fragment (3). "this is not just related to the job"

(ManB: manager B, E = female employee)

$01 \mathrm{ManB}$ : this ${ }^{1}$ is not just caused by the job (.) I mean [it= detta påverkas ju inte bara av jobbet (.) alltså [det=

$02 \mathrm{E}:$

$03 \mathrm{ManB}$ : =is caused by so many things

=påverkas ju av så jättemycket

$04 \mathrm{E}$ : =that is what I mean because that's what I'm saying that it=det är det jag menar för det är ju det jag säger att de- 
06 next weekend and there are those things that will take place nästa helg och det är lite sånt som ska vara

07 at our house and there are yeah so there are many other things hos oss och det är ja så det är mycket annat

08 to fthink about ( ) $£$ att £tänka på $(\quad) £$

09 ManB: yeah absolutely

jo absolut

$10 \mathrm{E}: \quad$ so it's not just work absolutely not

Så det är inte bare jobbet absolut inte

$11 \quad(0.4)$

$(0.4)$

$12 \mathrm{ManB}$ : no because see the important thing for me: is that if anything nej för för det viktiga för mi:g är ju att om nåt

13 in the stress he:re (.) is something we can do something about i stressen hä:r (.) är nåt vi kan påverka

if you understand me [then we'll= om du förstår mig [så ska vi=

$16 \mathrm{ManB}:=0 f$ course try to find solutions to it =naturligtvis försöka att hitta lösningar på det

$17 \mathrm{E}$ : no but and it's just- (.) temporary I mean it

18 isn't anything that I feel [absolutely all the time but $I=$ är inte nåt som jag känner [absolut hela tiden utan jag=

$19 \mathrm{ManB}$ : [no [nej

$20 \mathrm{E}$ : =think (1.5) I don't think the work tempo has been like =tycker (1.5) jag tycker inte arbetstempot varit nåt sånt 21 extreme in general? during the year /.../ här extremt för övrigt under året /.../

The employee E has previously mentioned feeling stressed from time to time, something which they return to in this fragment. The manager begins by introducing an alternative source of experienced stress: "things" outside of the workplace and the fact that experienced stress is "caused by so many things" (line 03). E accepts the manager's proposed explanation (lines 02, 04-08) and even proffers examples of the manager's point in listing personal activities that have contributed to her stressful situation. Her turn is partly marked by production problems (repetition, fragmentation), which could signal an awareness that her admission of experienced stress, and in particular, stress that is not work-related, is not in line with preferred approaches to stress in the organization. The proposed analysis of more personal reasons underlying her stress is further confirmed by the manager in line 09 ("oh yeah absolutely"), something which E also concludes in line 10 ("so it's not just work absolutely not").

In lines 12-16, the manager provides $\mathrm{E}$ with further confirmation that it is jobrelated stress alone that is of interest in this context, "the important thing for me: is that 
if anything in the in the stress he:re (.) is something we can do something about”. Retrospectively, then, the manager frames E's prior accounts as partly inappropriate (dispreferred) as some of her experienced stress can be attributed to factors in her personal life. The parts of her stress that belong to her personal life are, consequently, not relevant to him, and the parts that originate in her working life are those parts that "we" (i.e. the organization/the management, possibly together with the employee) should "try to find solutions to it" (lines 14,16). Again, as we saw in the previous two fragments, individual experiences of stress are conceived of as something that can be broken down, separated, and isolated into units that can be labeled, such as positive/negative, or personal/workrelated. Here, as in fragment (1), responsibility for causes of stress is openly assigned to one party. In fragment (1), the employee himself attributed the experience of stress to individual characteristics, whereas here, the manager carves out the organizational responsibility for employee well-being to encompass only stress that can be directly traced to the workplace. This, in turn, puts an effective stop to any further attempts on part of the employee to elaborate on problems of work-life balance, since experiences of stress, according to hidden organizational norms, can be clearly defined as belonging to one of the two spheres instead of to the intersection of work and private life.

Furthermore, in their conduct, participants display that only certain types of experienced stress are legitimate. In fragment (1), positive and adrenaline-generating stress is cast as acceptable and even desirable, and in fragment (3), work-related stress is portrayed as the only appropriate stress to discuss in PAIs. The employee promptly adjusts to this approach, and frames stress in relation to work (fragment 1) or private life (fragment 3). In fragment (3), the employee also strongly downgrades her previously admitted stress level by classifying it as "temporary" and framing it in the perspective of the entire year, where the tempo has not been "like extreme". Such mitigations further liberate the workplace from any further responsibility, and do not invite further probing into the described experiences of stress.

The sequences analyzed above all illustrate how preferred and dispreferred approaches to stress are talked into being in performance appraisal interviews. In all three excerpts, participants do interactional work to tone down experienced or potential stress, and to upgrade stress that can be viewed as optimizing performance. In addition, responsibility for so-called negative stress is assigned to individual employees i.e. to their disposition or their private arrangements. Participants manifest social norms by orienting to local preference structures built into the local context and the institutional culture. As a consequence, norms are continuously made visible, reconstructed, and reinforced in the performance appraisal interview. As long as people align with underlying norms, they are relatively invisible both to outsiders and to participants themselves. People thus orient to such hidden curricula without explicitly knowing that they are doing so. Talking about stress in an abstract sense, i.e. in a way that does not particularly concern the individual or her/his experiences is not problematic per se in performance appraisal interviews. However, it is clear that in our data, certain perspectives on stress are favored, whereas others, such as voicing experiences of negative stress, pose challenges to employees in terms of the inherent risk of interactional problems.

If institutional norms promote an image of appropriate employeeship that includes certain approaches to stress, acknowledging an inability to manage emerging stress becomes a norm violation, which in turn would showcase the employee in a less favorable light in the eye of the organization. As such, the performance appraisal interview be- 
comes a danger zone for employees rather than an arena for problem identification and resolution. Since these norms are collaboratively reconstructed by both managers and employees in the talks, it becomes not only structurally difficult, but also individually risky, to admit to experienced stress or work-life imbalance while at the same time fitting into the mold of the ideal employee.

\section{Implications for organizations and employees}

As demonstrated in our analyses of fragments, the good employee, or the 'ideal worker' (Acker, 1992; 2006) in our material appears to be a person who can navigate workplace stress and overload, who views stress as something positive, and who is able to distinguish between stress connected to work and other potential stressors. As such, the PAI as a communication event becomes a site for both the display of institutional norms for employee ideals, and the upholding of such norms in the joint construction of preferable approaches to stress. Through our examination of recorded PAIs, we argue to have demonstrated that coming to terms with 'real' dilemmas of workplace stress can be difficult within the framework of this particular arena. Limited opportunity is provided for examining more deeply the causes of stress, and experiences of stress that have been raised are subsequently downgraded, marginalized, and mitigated collaboratively by managers and employees. In essence, the guiding principle is that the ideal employee is not stressed, sees the positive side of stress, and is able to manage stress in daily life.

The hidden curriculum for the ideal employee in our data bears many similarities with the gendered 'ideal worker' norm articulated by Acker (1990; 1992; SOU 1997:139) and others. Being available and work-oriented, able to distinguish between positive and negative experiences of stress and also, able to discern between private and work-related stressors are characteristics that both managers and employees in our data display orientations to. As a consequence, it is easier for employees that fit with the masculine ideal worker to keep the impingement of life outside work at bay if a spouse/partner assumes the main responsibility for home and family. The organizational norms reinforced in the PAI may therefore benefit some employees more than others, and bear with them more negative consequences for women as employees, something which we have discussed elsewhere (Cf. Jakobsen et al. 2010). The ideology of the good employee presupposes an individual who puts the conditions of work first. Besides the demands of working life, women are to a greater extent affected by societal (and internalized) demands and expectations on parenthood, domestic care, and extended family responsibilities, which in turn means that women run a greater risk of deviating from the norm of being flexible, careeroriented, and capable of handling stress. As an example, the performance appraisal interview is closely connected to the evaluation of job performance, and as such, the link to wage-setting is inevitable. This means that it is not unproblematic for employees to reveal qualities or values that do not fit nicely with the hidden agenda of the ideal employee.

\section{Concluding remarks}

In this paper, we have illuminated some pitfalls in the performance appraisal interview as an arena for negotiating experienced stress. Instead of making visible and 
solving structural problems, the PAI may contribute to consolidating ethical ideals of 'the good employee' which in turn make interactions that display negative orientations to stress problematic. A consequence of this problematicity is that structural issues face the risk of remaining unresolved. In order for the PAIs to work effectively and sustainably as tools for improving conditions in working life, increased attention to the performance appraisal interview as a communication event, where managers' formulations set the boundaries for employee contributions, is called for. We argue that the attention to participant orientations in the interview provided new insights into the opportunities available to employees, and to the interactional consequences of manager formulations regarding preferred orientations to stress. The employee is, as Kristensen (2003) argues, placed in a panopticon, which is a vulnerable position with few opportunities for voicing concerns that deviate from the norm. Furthermore, the responsibility for experiences of 'negative' stress is assigned to the individual employee rather than to the organization. There are, in our view, good reasons to assume that the performance appraisal interview is a problematic site for negotiating matters of stress and work-life balance.

Other arenas for managing these issues are possible; however, such arenas need to be examined carefully in further research. An option of more collective nature is that the workplace finds forms of interaction and dialogue in groups where the individual is not as exposed as in manager/employee dyads. In such interactions, structural problems could possibly be managed without reference to personal circumstances. The data presented in this paper is limited to one organization, which naturally bears consequences for generalizability of our findings. However, we encourage studies of PAIs in different organization types, and with varying topical foci, such as formal job evaluation, job satisfaction and employee well-being, and individual development plans. Such interactions need to be studied with the same devotion to details of the social interplay as individual performance appraisal interviews deserve and need.

\section{Appendix}

Transcript notations (adapted from Atkinson \& Heritage, 1984, pp. ix-xvi).

:

\section{Underlining}

(.)

(( ))

$($ )

;

$?$

$\uparrow \downarrow$

${ }^{\circ}$ word $^{\circ}$

[ ]
Colon(s). Extended/stretched sound, syllable or word. Not only vowel sounds.

Empasis

Brief micropause of less than (0.2) seconds.

Timed Pause, within or between turns.

Double parentheses, notation of scenic details

Transcriptionist doubt

Period: falling pitch.

Rising vocal pitch, not necessarily a question

Marked rising and falling shifts in intonation

Passage of talk noticeably quieter than surrounding talk

Overlap 
!

Whe-

$<>$

hhh

.hh

Mo(hh)re

(pt)

Hah heh hoh

$£$

MINE
Animated tone

Hyphens: halting or abrupt cut off sound or word

Noticeably quicker $(><)$ or slower $(<>)$ than surrounding speech

Audible aspiration, possibly laughter.

Audible inbreath

Within-speech aspiration, possibly laughter

Lip smack

Relative open/closed position of laughter

Smile voice

Speech noticeably louder than surrounding speech

Indication to readers to pay special attention to line in transcript

\section{References}

Acker, J. (1990): Hierarchies, Jobs, Bodies: A theory of gendered organizations. Gender \& Society, 4 (2), 139-158.

Acker, J. (1992): Gendering organizational theory. In Mills, A.J. \& P. Tancred (Eds). Gendering Organizational Analysis. Sage: Newbury Park, 248-260.

Acker, J. (2006): Inequality regimes: Gender, class, and race in organizations. Gender \& Society, 20 (4), 441-464.

Adelswärd, V. (1988): Styles of Success. On impression management as collaborative action in job-interviews. Doctoral dissertation. Linköping Studies in Arts and Sciences, 23, Linköping.

Antaki, C. \& Widdicombe, S.(1998): Identities in Talk. London: Sage.

Asmuß, B. (2006). En undersøgelse om medarbejderudviklingssamtaler $i$ en større dansk virksomhed. Aarhus School of Business: Center for Virksomhedskommunikation.

Asmuß, B. (2008): Performance appraisal interviews. Preference organization in assessment sequences. Journal of Business Communication, 45 (4), 408-429.

Atkinson, J. M. \& J. Heritage (Eds.). (1984): Structures of Social Action. Studies in Conversation Analysis. Cambridge: Cambridge University Press.

Drew, P. \& J. Heritage (1992): Analyzing talk at work: an introduction. In P. Drew \& J. Heritage (Eds.). Talk at Work. Interaction in Institutional Settings. Cambridge: Cambridge University Press.

Drucker, P. (1955): Practice of management. London: Heinemann.

Engquist, A. (1990): Utvecklingssamtal som förändringsinstrument. Teoretisk och empirisk analys. Uppsala Studies in Education, 36. Acta Universitatis Upsaliensis.

Engström, P. (2005): Samtal och ledarskap - en studie av medarbetarsamtal i grundskolan. Doktorsavhandling. Sociologiska institutionen, Göteborgs universitet.

Fellinger, Å. (2005): Svære medarbejdersamtaler. Bliv en bedre chef. Copenhagen, Denmark: Jyllands-Postens Forlag.

Foucault, M. (1997): Ethics: Subjectivity and Truth. In P. Rabinow (Ed.). The Essential Works of Michel Foucault 1954-1984. Vol 1. New York: The New Press.

Garfinkel, H. (1967): Studies in Ethnomethodology. Englewood Cliffs: Prentice Hall.

Gordon, M. E. \& L. P. Stewart (2009): Conversing about performance. Discursive resources for the appraisal interview. Management Communication Quarterly, 22 (3), 473-501.

Granath, G. (2008): Milda makter! Utvecklingssamtal och loggböcker som disciplineringstekniker. Göteborgs universitet: Göteborg Studies in Educational Sciences, 2008:263.

Grote, D. (2000): The secrets of performance appraisal. Best practices from the masters. Across the Board, 14-20. 
Heritage, J. (1984): Garfinkel and Ethnomethodology. Cambridge, UK: Polity Press

Hermansson, J. (2004): Kan man tala om psykisk belastning under utvecklingssamtalet? En intervjustudie på tre sjukvårdsavdelningar. Enheten för Psykisk Hälsa, Samhällsmedicin, Stockholms läns landsting, 2004: 3.

Hofvendahl, J. (2006): Riskabla samtal - en analys av potentiella faror i skolans kvarts- och utvecklingssamtal. Doktorsavhandling. Linköping Studies in Arts and Science, nr 338. Arbetslivsinstitutet, 2006: 1.

Holte, K. (2009): Hysj: en kritisk didaktisk relasjonsanalyse av Curriculum Silentium; den skjulte policyen for taushet om arbeidsrelatert kritikk hos ansatte. Karlstad: Karlstads universitet. Accessed at: http://urn.kb.se/resolve?urn=urn:nbn:se:kau:diva-4405

Horn, R. A. JR (2003): Developing a Critical Awareness of the Hidden Curriculum through Media Literacy. The Clearing House, 76 (6), 298.

Jackson, P. W. (1968): Life in classrooms. New York: Holt, Rinehart \& Winston.

Jakobsen, L. (1999): Livsform, kön och risk: en utveckling och tillämpning av realistisk livsformsanalys. Lund: Arkiv

Jakobsen, L, Nahnfeldt, C., Nyroos, L., Olin-Scheller, C., \& Sandlund, E. (2010): Medarbetarsamtal som arena för att befästa normer kring medarbetarskap. Arbetsmarknad \& Arbetsliv, 16 (3), 39-54.

Jäghult, B. (1988): Planeringssamtalet: det individuella samtalet mellan chef och medarbetare om relationer och arbetsplanering. Malmö: Liber.

Jönsson. G. (2004): Utvecklingssamtal och andra samtal som ledningsinstrument, Stockholm: Norstedts Juridik.

Kristensen, M. (2003): Disciplinerende dialoger - medarbejdersamtalen som socialteknologi. Handelshojskolen i Aarhus Center for Virksomhedskommunikation: Working paper 1.

Lindgren, M. (2001): Utvecklingssamtal mellan chefer och medarbetare. Undersökning av en samtalstyp i arbetslivet. Lund University: Lundastudier i nordisk språkvetenskap, A 56.

Markström, A-M. (2009): The parent-teacher conference in the Swedish preschool: A study of an ongoing process as a "pocket of local order". Contemporary Issues in Early Childhood, 10 (2), 122-132.

Mikkelsen, A. (1998): Medarbetarsamtal och lärande i organisationer. Lund: Studentlitteratur.

Pomerantz, A. (1984a): Agreeing and disagreeing with assessments: some features of preferred/dispreferred turn shapes. In J. M. Atkinson \& J. Heritage (Eds.). Structures of Social Action. Studies in Conversation Analysis. Cambridge: Cambridge University Press, 57-101.

Roberts, G. E. (2002): Employee Performance Appraisal System Participation: A technique that works. Public Personnel Management, 32 (1), 89-98.

Redegard, M. (2006): Såsom i en spegel. Elevers upplevelser av utvecklingssamtal. Kalmar: Högskolan i Kalmar.

Sacks, H., Schegloff E. A. \& Jefferson, G. (1974): A simplest systematics for the organization of turn-taking for conversation. Language, 50 (4), s 696-735.

Sandlund, E. (2004): Feeling by doing: the social organization of everyday emotions in academic talk-in-interaction. Karlstad University Studies, 2004: 36. Karlstad: Karlstad University.

Scherp H-Å; Scherp G; Johansson P-O \& Jönsson E (2004): Lärande medarbetarsamtal. Karlstad: Karlstad University.

SOU 1997: 139: Hemmet, barnen och makten. Förhandlingar om arbete och pengar $i$ familien. 
Thornberg, R. (2004): Dunkla vrår i skolans värdepedagogiska praktik. In G. Colnerud (Ed). Skolans moraliska och demokratiska praktik. Linköping: Linköpings universitet, 27-48.

Tienari, J., Quack, S. \& Theobald, H. (2002): Organizational reforms, 'Ideal workers' and gender orders: A cross-societal comparison. Organization Studies, 23 (2), 249-279.

\section{End note}

1 i.e. the experience of stress, mentioned in preceding turns. 